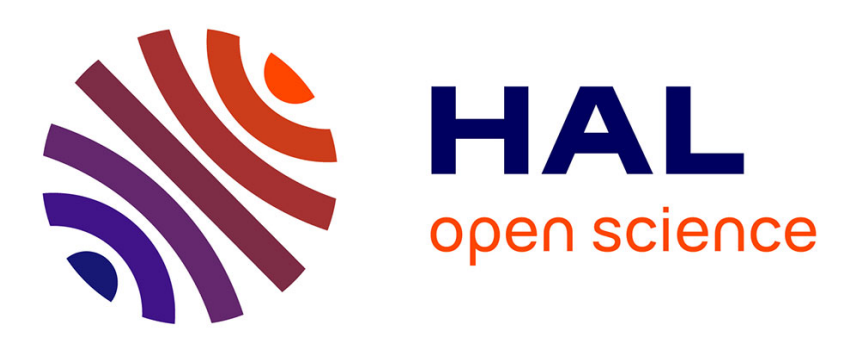

\title{
The EEC/EU as an Evolving Compromise between French Dirigism and German Ordoliberalism (1957-1995)
}

Laurent Warlouzet

\section{- To cite this version:}

Laurent Warlouzet. The EEC/EU as an Evolving Compromise between French Dirigism and German Ordoliberalism (1957-1995). Journal of Common Market Studies, 2018, 57 (1), pp.77-93. 10.1111/jcms.12817 . hal-02512294

\section{HAL Id: hal-02512294 \\ https://hal.science/hal-02512294}

Submitted on 1 May 2020

HAL is a multi-disciplinary open access archive for the deposit and dissemination of scientific research documents, whether they are published or not. The documents may come from teaching and research institutions in France or abroad, or from public or private research centers.
L'archive ouverte pluridisciplinaire HAL, est destinée au dépôt et à la diffusion de documents scientifiques de niveau recherche, publiés ou non, émanant des établissements d'enseignement et de recherche français ou étrangers, des laboratoires publics ou privés. 


\title{
The EEC/EU as an Evolving Compromise between French Dirigism and German Ordoliberalism (1957-1995)
}

\author{
LAURENT WARLOUZET \\ University of Littoral-Côte d'Opale, France
}

\begin{abstract}
This contribution explores the origins of the mutation of the concept of the 'social market economy', from its ordoliberal roots, to its contemporary broader meaning, by examining to what extent it was influenced by the perennial debate between French dirigism and German ordoliberalism. After an initial section defining both concepts, the contribution proceeds to unearth long-forgotten conflicts between both approaches from the 1960s to the 1980s on European planning, on industrial policy and on competition policy. A final section delves into the Delors synthesis and the EMU compromise.
\end{abstract}

Keywords: Ordoliberalism; industrial policy; competition policy; planning; France

\section{Introduction}

The concept of the 'social market economy', which is now encapsulated in the European Union Treaty (Article 3 TEU) has always been ambiguous. Coined by Alfred MüllerArmack, a German thinker often associated with ordoliberalism, it has also been claimed by leaders influenced by the French dirigist tradition - such as the French socialist party, which has stood as an official defender of a 'social and ecological market economy' since 2008. ${ }^{1}$

To overcome this ambiguity, this contribution will gauge to what extent German ordoliberalism and French dirigism have influenced the history of the EEC/EU, and its definition as a 'social market economy'. It argues that both traditions have had an enduring impact on the EEC/EU, visible both in their conflicts, and also in the synthesis that the Jacques Delors Commission strived to promote.

French dirigism and German ordoliberalism represent relevant case studies because they lie at both ends of the economic policy spectrum. As argued in Governing Europe in a Globalizing World (Warlouzet, 2018), post-1945 economic policies can be divided into three categories: socially-oriented ones, neomercantilist ones and market-oriented ones. Socially-oriented policies are aimed at protecting those more fragile groups, such as the poor, through legislation and redistribution. Neomercantilist policies associate the mercantilist's aggressive stimulation of national industrial potential with tolerance towards the international free-trade order (hence the prefix 'neo'). Blatant protectionism has not been possible from the 1960s onwards, but more discreet measures, such as state aid or non-tariffs barriers, are still possible. Finally, market-oriented policies put an emphasis

\footnotetext{
${ }^{1}$ On ordoliberalism, see below (part I), and also see Matthieu Segers' and Anna Gerbrandy's contributions to the this Special Issue; on French socialists and the social market economy: Déclaration de principes du Parti socialiste, Paris, 14 June 2008, Article 6, source: http://discours.vie-publique.fr/notices/083002288.html (accessed 22 November 2017).
} 
on free-market dynamics because they are believed to unleash growth. Whereas, French dirigism can be associated both with neomercantilism and with socially-oriented policies, ordoliberalism clearly fits into the 'market-oriented' category. It is even sometimes associated with neoliberalism, although this is disputed. For example, Stephanie Lee Mudge refuses to associate ordoliberalism and neoliberalism because the former does not recognize the self-regulatory character of markets, and put an emphasis on social and moral values (Mudge, 2008).

To address this question, this contribution will retrace the origins of the EU, namely the Treaty of Rome of 1957 creating the European Economic Community, up to the Maastricht Treaty, when Jacques Delors advocated a new Franco-German compromise. It will draw on new evidence from French, German, EU and European archives. ${ }^{2}$ As a result, it intends to make three contributions to the literature. First, this research dovetails with explorations into the interrelations between national and European economic policies (Fioretos, 2011; Schmidt, 1996; Thatcher, 2007). By bringing to the fore new archival evidence, this contribution unearthed previously ignored controversies, in particular those between ordoliberal supporters of competition policy and promoters of planning and of industrial policy. Second, it complements the literature regarding the history of European integration, which has often framed the Franco-German economic debate as a trade-off between French agricultural exports and German industrial exports. While not wholly untrue, this assertion is unduly simplistic. French leaders have always considered the EEC/EU as a useful boost for their industry, while some German officials have sometimes promoted higher prices for agricultural products than the French (Knudsen, 2009).

Crucially, this contribution does not claim that only French dirigism and German ordoliberalism have influenced the EEC/EU economic policies. Nor does it claim that national actors are unitary and that only nation-states have been influential within the EEC/EU. The first assertion is easily refuted by the fact that the Dutch government played a greater role than most other member states in the early development of the Common Agricultural Policy (CAP) (Knudsen, 2009). Similarly, the British government was instrumental in the birth of the regional policy, and subsequently in the neoliberal agenda of the Thatcherian era. This contribution simply asserts that French and German leaders, in Paris, Bonn or Brussels, were arguably the most influential players in the early decades of EEC/EU history, but not the sole relevant ones (Moravcsik, 1998). The second idea would mean that all national actors could be associated with only one single ideology, whereas this contribution will provide a multitude of counter-examples. Regarding the third claim, whereas the contribution will put an emphasis on national governments, it will also consider the European Commission as another arena in which both these ideologies clashed.

The initial section introduces the main concepts, French dirigism and German ordoliberalism. The following section examines the contest between those two visions during the Golden Age, animated by a debate between competition policy and planning. The third section explores the 1980s, when a new struggle over industrial and competition policies erupted. The final section examines the Delors synthesis and its main legacy, the European monetary union.

\footnotetext{
${ }^{2}$ Only a sample of archives are cited in this contribution. For most extensive quotations, see Warlouzet, 2016 and Warlouzet, 2018. For the purpose of this study, archival sources were consulted for the period up to the end of the 1980s.
} 


\section{French Dirigism and German Ordoliberalism}

The formation of the nation-state occurred very differently in both France and in Germany. It is usually considered that while in Germany the nation preceded the state, the reverse was true in the French case (Brubaker, 1992). While this assertion is certainly exaggerated, elements of French popular patriotism being visible as early as the $\mathrm{XV}^{\text {th }}$ Century with the Joan of Arc episode (Beaune, 1993), it is certain that the French state has played a dominant role in the formation of the French nation. The state was entrusted not only with the traditional task of ensuring law and order, but also with the promotion of the arts and of economic prosperity.

The responsibility of the state included the promotion of what is now called 'strategic industries' as far back as the late XVII ${ }^{\text {th }}$ Century, when Jean-Baptiste Colbert held a position akin to minister of Economy and Finance (1665-1683) of King Louis XIV. He waged an active policy - later on dubbed as 'colbertism' - aimed at bolstering the French manufacturing output through high custom duties on imports of competing products, and through the promotion of the most dynamic entrepreneurs by setting up 'Royal manufactures', or/and by granting monopolies. This policy of aggressive state promotion of national industry, in particular by protectionism, is known as mercantilism. At the same time, Colbert was not hostile to free-market dynamics. He set up national standards to improve the quality of production. He lowered the duties on raw materials imported to supply French manufacturers, and he dismantled part of the internal custom duties in order to unify the national French market. Lastly, Colbert strived to attract skilled foreign workers, such as Venetian glassmakers, German ironworkers or Walloon coalminers. Some companies set up under Colbert are still thriving today such as Saint-Gobain, one of the world leading producers of glass.

After 1945, with the rise of Keynesianism and the discredit of laissez-faire policy, this approach went yet further. French state officials were entrusted with the task of reconstructing and modernizing the economy, whereas private actors were considered too conservative and inward-looking. This translated into the establishment of a comprehensive state-led social security scheme, the nationalization of vast swathes of the economy (transportation, raw materials, some banks), the inception of an indicative planning (when the Commissariat général au Plan was set up in 1946, see below), and lastly in the support of 'grand projects' in high technology (the aircrafts Concorde and Airbus, the high-speed train TGV, etc.) (Schmidt, 1996). As a result, French dirigism acquired a more social dimension, in addition to a strong neomercantilist orientation. Dirigism also affected other Western European countries after 1945, even the UK with the creation of the NHS, but usually to a lesser extent.

At the same time, this dirigism was combined with a free-market economy. When he returned to power in 1958, De Gaulle ensured that France fully embraced international free-trade liberalization (Warlouzet, 2011). Over the course of the 1960s and the 1970s, Paris had always supported free-trade at the EEC and at the GATT level, even though it had followed the more cautious position of the British and the Italians, rather than the more open one of the Dutch, the Belgians and the Germans (Coppolaro, 2013, 2016).

\section{German Ordoliberalism}

In 1949, dirigism was not an option for the new Federal Republic of Germany, as it wanted to dissociate itself from Hitler, who had waged an aggressive mercantilist policy. 
However, German officials did not embrace full market liberalization either. Peter Hall and David Soskice have famously described Germany as the embodiment of the "coordinated market economies', whereby firms rely more on non-market relationships than in 'liberal market economies' where firms co-ordinate their activities via the market (Hall and Soskice, 2001, pp. 8, 27). The co-ordination of actors does not hinge on the central state, as in France, but on a range of decentralized actors such as local authorities, independent bodies (such as the Bundesbank), non-profit actors (such as churches), large local banks, and corporatist relationships between companies and trade unions (Katzenstein, 1987). Moreover, German economic liberalism was mixed with an ancient 'Sozial Staat' created by Bismarck in the 1880s, and with a tradition of consensus and of legalism, which predates 1945 (Dyson, 1992).

The post-1945 intellectual landscape was marked by the rise of ordoliberalism, an economic school of thought, which was both a reorientation of economic thinking after the world economic crisis, and a reaction against national-socialism, which combined totalitarism, capitalism and economic dirigism (Gerber, 1998; Nicholls, 1994). The ordoliberals, such as Walter Eucken, Franz Böhm or Wilhelm Röpcke, promoted a new role for state authorities as guardian of all individual and collective freedoms, both in the political realm (freedom of speech, etc.) and in the economic arena (freedom of choice for consumers, freedom of small companies to be protected from big corporations, etc.). Beyond this fundamental mission, the State's role should be limited by an economic constitution which would impose the same rights and duties for every actor, including the State. The only period of German history associated with centralism and dirigism was the national-socialist one (with the exception of WWI). In reaction, ordoliberals considered that the public authorities should not meddle with free-market dynamics through discriminatory policies, but should instead remain as neutral as possible.

This ideology had certainly influenced post 1945 German economic policy to some extent through the establishment of authorities which were given extensive powers and a wide autonomy from the national government, such as the German central bank (the Bundesbank, 1957) and the German competition authority (Bundeskartellamt, 1957). These decisions embody the ordoliberal notion of an order-based economy, wherein public authorities strived to construct a market based on free competition by imposing the same rules on all actors, whereas dirigism is based on explicit political choice to favour certain economic actors ('picking the winner').

This German situation was quite peculiar. In most Western European states, central banks were dependent on governments, and hardly any competition policy existed until the 1980s. In France for example, the competition policy authority became genuinely independent from the government in 1986, while the Banque de France became independent only in 1994 as part of the framework of the transition toward the Economic and Monetary Union.

The ordoliberal influence was also visible in the network of individuals surrounding Ludwig Erhard, arguably Germany's most powerful official in the economic realm between 1949 and 1966, when he was Minister of Economics and then Chancellor. Müller-Armack, who is usually associated with ordoliberalism even though he was not opposed to a targeted state role in social policy (Nicholls, 1994, pp. 139-144), was deputy minister to Erhard. As Matthieu Segers' contribution highlights, Wilhelm Röpcke influenced Ludwig Erhard's thinking. However, it is always difficult to ascribe any one 
single economic thought to a politician. Even Erhard strived to protect Germany's mighty companies from an ordoliberal-inspired competition policy, which could have weakened them (Berghahn, 1986, p. 158).

In sum, for ordoliberals, economic policy should be largely driven by independent public authorities which should act as neutral referees. For dirigists, the central state must make explicit political choices, and use its numerous tools to steer the economy. Both of these approaches were influential because they were considered part of the explanation for the exceptional growth rates enjoyed by these countries between 1945 and the 1973 oil shock. During those decades, both countries caught up with the USA and were overtaken only by Japan's growth rate.

These approaches also affected the European institutions, in particular with the 1957 Treaty of Rome. Many other influences were also visible, including US ones (see Matthieu Segers' contribution to this Special Issue). As a framework, the Treaty of Rome was flexible enough to accommodate many different economic approaches, as Article 2 and 3 EEC stating its aims illustrates. Obviously, the European Economic Community fit into the market-oriented category since the establishment of 'The Common Market' was its central mission. At the same time, however, the EEC was also compatible with neomercantilist measures: Article 222 EEC protected nationalized companies and the provisions on competition policy were vague enough to leave national industrial policies unimpeded. The social side of the EEC was visible first in the fact that the Community did not prevent nation-states from expanding their national welfare state (Milward, 1992), and also in the promotion of specific social measures, such as targeted assistance for the poorer regions, provisions for migrant workers and targeted social harmonization. Article 117 EEC stated that the Treaty was designed to 'to promote improvement of the living and working conditions of labour so as to permit the equalisation of such conditions in an upward direction'. Hence, everything depended on the interpretation of the Rome Treaty.

\section{During the Golden Age: Competition or Planning}

After the signature of the Rome Treaty in 1957, three common policies were set up in the 1960s: the establishment of the common market, the external commercial policy (Coppolaro, 2013), and the Common Agricultural Policy (Knudsen, 2009; Patel, 2009). Some European commissioners wanted to go further. Officials inspired by the German experience devised an ambitious project of competition policy, while their counterparts who were influenced by French dirigism sought to foster European planning.

\section{Competition Policy}

For ordoliberals, competition policy (the control of cartels and monopolies) is part of an economic constitution designed to ensure that individual freedom is guaranteed by controlling agreements that could result in excessive accumulations of power. As a result, German officials passed an ambitious national competition law in 1957 which symbolized a break with the past, as the National-Socialist era was associated with cartelization (Gerber, 1998, pp. 232-265). Other western European countries had competition laws but they were less comprehensive than the German one, and the authorities in charge of 
enforcing it were usually weaker and less independent than the Bundeskartellamt created in 1957. In West Germany, competition policy formed an independent domain, whereas in other countries it was usually subjected to other public policies, such as price policy or industrial policy.

Some German officials wanted to translate this system at the EEC level. The Treaty of Rome contained ambitious competition rules but there was ample scope to interpret their content both in terms of substance and in terms of procedure (Warlouzet, 2016, pp. 729-731). Hans von der Groeben, the first Commissioner for Competition and a staunch supporter of European integration (Elvert, 2004), was willing to take inspiration from the German experience in the implementation of the Rome Treaty. As a matter of fact, Germans clearly dominated the Directorate General in charge of competition, even if the Director General was the Dutchman Pieter Verloren van Themaat (Seidel, 2010). Van Themaat tried to promote another vision of cartel policies but he was sidelined by the Germans (Ramirez-Perez and van der Scheur, 2013). In 1962, this translated into the regulation $17 / 62$ on cartel control. ${ }^{3}$ It gave extensive powers to the Commission, which thereby received a monopoly on information, via the notification procedure, and on decisions to authorize a cartel. A committee of member state experts was set up but it was merely consultative.

Regulation 17/62 was a Europeanization of the German system. Both were based on erecting competition policy as a powerful and independent public policy, and on vesting a range of powers in one independent institution. However, it was not a pure adaptation, since the Commission was a political organization, whereas the Bundeskartellamt was an administrative authority with a broad degree of independence from the government. Other models had been proposed during the negotiations, as the Treaty of Rome was open to interpretation (Warlouzet, 2016).

Moreover, von der Groeben had an ambition that extended beyond cartel control. In a speech before the EEC Council of Ministers in February 1960, just before launching the negotiation which would eventually lead to Regulation 17/62, von der Groeben explained that it was necessary to wage an active competition policy at the EEC level for two compelling reasons. ${ }^{4}$ First, with the reduction of public trade barriers (custom duties and quotas) under way, it was important to monitor private obstacles to trade such as cartels, in order to ensure that the latter would not replace the former. Second, von der Groeben aimed at 'homogeneity', namely the implementation of the same competition policy in every EEC country. This was quite bold since three of the six member states had no national competition policy at all. On 16 June 1965, he explained that the entire EEC 'economic policy' had to be driven by competition policy norms. ${ }^{5}$ Thus, all state intervention in the economy had to be kept to a minimum if it infringed on free-market rules. This interpretation clearly brings von der Groeben close to interpreting the Treaty of Rome as an economic constitution, much like the ordoliberals did within the German framework.

This quest led von der Groeben to clash with French dirigism. He commissioned a German professor to examine national interventions in the economy, with a special focus on France. The aim was to ensure that French industrial policy abided by the Treaty of

\footnotetext{
${ }^{3}$ For a review of the literature on this negotiation, see Warlouzet, 2016.

${ }^{4}$ EU archives, BAC 1/1971/80/78, note R/68/60, 21 January 1960.

${ }^{5}$ Archives of the French foreign affairs ministry, RPUE 615, Hans von der Groeben's discourse, 16 June 1965.
} 
Rome's competition rules, including Article 92-94 EEC on state aid. The Commission successfully managed to force the French government to slightly alter some of its aid plans, but only around the margins (Warlouzet, 2011). In Brussels, von der Groeben clashed at the college of commissioners with his colleague, the French socialist Robert Marjolin. When the latter promoted European planning (see below), von der Groeben forcefully asserted that all European economic policies had to be inserted within a free-market framework based on competition rules (Von der Groeben, 1964). Within the Commission, he multiplied the criticism against the planning project (Warlouzet, 2011, pp. 374-376).

On the whole, however, the attempt to forge an EEC based on an ordoliberal-inspired competition policy remained theoretical. The EEC constraint remained extremely limited due to the fact that national industrial policies were all-powerful in this era of 'embedded liberalism' (Buch-Hansen and Wigger, 2011; Ruggie, 1982). Even the German government opposed von der Groeben in some areas, for example when the Commission attacked an agreement involving a German company (Warlouzet, 2018, p. 158). Most of all, the European Commission's competition policy was constrained by its own administrative limitations. Regulation 17/62 imposed a system of compulsory notifications of agreements on the Commission, which led to more than 36,000 notifications in a few months. Von der Groeben's team was overwhelmed by the resulting workload and was not able to reach decisions in the vast majority of these cases, creating the so-called 'backlog problem'. This opened the door for an alternative interpretation of the Rome Treaty, informed by French dirigism, namely planning.

\section{European Planning}

The French Commissariat general au Plan (General Planning Commissariat) was founded in 1946 to co-ordinate the process of reconstructing the economy at a time of scarce resources. Its staff was limited since it was mostly a body of consultation and of informal co-ordination. Its task was to set up a non-binding Five-year Plan after a large consultation of political, administrative, social and economic actors. This process of 'indicative planning' (from the French 'planification indicative') was not compulsory as in the Soviet Union, especially for private economic actors, which remained entirely free. The Plan was influential because it was a document of reference, and because the State controlled many levers to constrain private companies, such as most access to funding. It was useful for private companies as an exercise in long-term forecasting. The French President Charles de Gaulle (1959-69) reformed the planning process. In a speech of 8 May 1961, he called it an 'ardent obligation'. ${ }^{6}$ As a result, the Fourth Plan (1962-65) had a larger remit. It included social aims, and put an emphasis on social investment (like hospitals, schools, sports facilities). There was even an attempt to put into place an income policy in 1963-64, that is to say a regulation of the progression of income by a collaborative process designed to ensure fairness and economic soundness. In sum, even if the term 'social market economy' was not used by French policy-makers in those days, indicative planning clearly associates the free-market with dirigism and social aims.

\footnotetext{
${ }^{6}$ Speech by Charles de Gaulle on French TV, 8 May 1961, INA website http://fresques.ina.fr/de-gaulle/fiche-media/ Gaulle00072/allocution-du-8-mai-1961.html. [accessed 23 September 2013].
} 
Planning was not exclusively a French domain. The idea emerged as a major theme of debate among public decision-making experts in the 1930s, in particular with the Belgian Henri de Man. After the war, planning agencies were developed in several countries. In 1965, Andrew Shonfield estimated that at least eight western European countries had a national economic planning agency or an equivalent procedure (Shonfield, 1965, p. 122). Several of these countries created their planning agency in the $1960 \mathrm{~s}^{7}$ According to Shonfield: 'economic planning is the most characteristic expression of the new capitalism. It reflects the determination to take charge rather than be driven by economic events' (Shonfield, 1965, p. 121). Characteristically, this sentence was placed in the introduction of the chapter on France. French planning was the focus of interest of many academics. The Harvard Business School dispatched a team of experts to study French planning, whose output was a book published in 1969 (McArthur and Scott, 1969).

The French socialist Robert Marjolin, who became the first Commissioner for Economic Affairs in 1958, exploited this favourable intellectual context. The first Secretary General of the OEEC (1948-55), he was at the centre of a large transatlantic network. Starting in 1962, he mobilized a transnational coalition of planning experts of several Western European countries to promote European planning (Warlouzet, 2011, pp. 339417). To assuage German fears, his projects bore the name of 'Programmation' or 'Mid-Term Economic Policy'. In 1964 a Committee on Mid-term Economic Policy was officially set up as a new EEC institution. Its aim was to gather top civil servants to exchange information about mid-term economic forecasting, and, in a second step, to co-ordinate those policies among themselves and with EEC policies. Marjolin used the methodology inspired by French planning: he tried to convince decision-makers rather than to coerce them. This was logical as member states were not ready to give up any powers in this area. Marjolin developed very ambitious aims, close to those heralded in the Fourth French Plan, namely to prioritize collective investments over individual consumption, which was seen as symbolic of the excesses of the mass consumer society.

On the other side of Rhine, West German officials remained deeply hostile to planning, which was associated with the reviled Soviet Union and with Eastern Germany. Certainly, in West Germany, the introduction of planning methods was discussed by experts and civil servants (Nützenadel, 2003, pp. 84-86), but the debate was limited to the improvement of forecasting for certain public policies. The German Economic Minister Ludwig Erhard, who professed a deep attachment to free-market rules, attacked the Marjolin Programme at the European Parliament in November $1962 .{ }^{8}$ Interestingly, the German President of the European Commission, the Christian-Democrat Walter Hallstein, intervened to defend his colleague's project. However, Hallstein did not use the same line of argument as Marjolin or the French planners. He deliberately included the 'Marjolin Programme' into a free-market framework, in particular by quoting Walter Eucken, an economist considered as one of the fathers of ordoliberalism. ${ }^{9}$ There was widespread opposition to the Europeanization of the French planning within the Commission, most of all from von der Groeben. Within the Council of Ministers, the German representatives constantly strived to undermine Marjolin's efforts by diminishing the remit of the

\footnotetext{
${ }^{7}$ Marjolin, R. (1963) 'Rapport général', in: La Programmation économique européenne et la programmation économique nationale dans les pays de la CEE, Florence, pp.11-29.

${ }^{8}$ European Parliament, Compte rendus des séances, séance du mardi 20 novembre 1962, Luxembourg, 55-6.

${ }^{9}$ Ibid, 69-71.
} 
proposed 'Committee on Mid-Term Economic Policy'. Eventually, Bonn accepted a compromise in 1964 whereby the Committee would only be consultative, and would be chaired by a German junior minister, Wolfram Langer (Nützenadel, 2003, pp. 90-91). Langer was close to actors influenced by ordoliberal thinking. ${ }^{10}$ In the end, Marjolin's project of European planning came to a halt because the French Gaullist government was hostile to the delegation of sovereignty that this project entailed. In 1965-96, the 'Empty Chair Crisis' relegated the 'Committee on Mid-Term Economic Policy' to a mere secondary role.

In conclusion, both the ambition to develop an ordoliberal-inspired European Community based on competition policy, and the European planning project largely failed in the 1960s. Member states were not ready to surrender their national sovereignty. The debate was revived after the economic crisis of the 1970s.

\section{Industrial Policy vs Competition Policy}

In the 1980s, the influence of EEC competition policy increased considerably for several reasons: the rise of neoliberal ideas, a new macro-economic context of stagflation which discredited Keynesian-inspired economic policies, and the initiatives of bold European commissioners (Buch-Hansen and Wigger, 2011; Cini and McGowan, 2009). This clearly affected French dirigist policies, which were directly targeted by the Commission. Some French actors, however, launched a counter-offensive based on the development of European industrial policies.

\section{State Aid Control Against French Industrial Policy}

While competition policy began in the 1960s with the control of private practices such as cartels, the Commission sought in the 1980s to target more public interventions through the control of state aid (granted by article 92-94 EEC). During the first two decades of the EEC, state aid control was almost non-existent. With the economic crisis of the 1970s however, the situation changed as all national governments poured billions into propping up their ailing national behemoths. As a result, member states had an incentive to empower the Commission to monitor state aid in order to avoid a subsidy race which would be extremely costly for all. In the 1980s, the dynamic new commissioners for competition, Frans Andriessen, Peter Sutherland and Leon Brittan developed state aid control more assertively. They targeted in particular French companies such as the mighty textile firm Boussac, which benefited from a massive aid package designed to avoid its terminal collapse in 1983-84. Andriessen launched an inquiry into Boussac. Sutherland took over the case. He decided to make an example of Boussac, such was the importance of the company, and the unwillingness of French officials to disclose information. He requested a massive repayment of FF 999 million by the company. After a heated debate within the Commission, and much pressure from the French government, Sutherland eventually settled for a compromise repayment of FF 338 million in 1987, a result that was still a massive blow for French authorities (Warlouzet, 2018, pp. 171-173). Later, Sutherland and Brittan launched high-profile cases involving state aid to French national champions such as Renault (1991). ${ }^{11}$

\footnotetext{
${ }^{10}$ German National Archives, B102/134647, letter from Wolfram Langer to Alfred Müller-Armack, 8 February 1961.

${ }^{11}$ EEC Commission decision of 22 May 1990, Aid to the Renault Group, Official Journal Reference: C 11 - 17/01/1991, p. 3 
The fight between Paris and Brussels over state aid was in fact a contest over dirigism. There was a mismatch between the rise of a market-oriented approach with Andriessen in Brussels, and the development of a bold neomercantilist policy with Mitterrand in Paris, both taking place in 1981. Whereas the level of French state aid was on par with the EEC average during the Giscard d'Estaing presidency (1974-81), it quickly rose to the top of the EEC under Mitterrand. ${ }^{12}$ This policy worried the German Ministry of Economics, which requested the Commission to subsequently monitor French state aid closely. ${ }^{13}$ In January 1982, Manfred Caspari, the Director General for Competition at the Commission, also originating from Germany, used the expression 'French problem' in a note to Andriessen. ${ }^{14}$

Many German officials supported the Commission in its quest (even if the Commission also targeted some German aid) as they feared a revival of mercantilism. In 1982, when the German Chancellor Helmut Schmidt criticized Mitterrand's neomercantilist policy in a discussion with the British ambassador, he used the expression 'Colbertist prejudice'. ${ }^{15}$ A few months earlier, the director general for competition at the Commission, the German Manfred Caspari, used the expression 'Colbertist delusion' without further explanation, as the reference was probably transparent according to him. ${ }^{16}$

\section{French Project of EEC Industrial Policy}

Facing this new challenge, several French officials strived to Europeanize their dirigist tendencies. In 1983, Michel Albert, a former head of the French planning agency, published A Gamble for Europe (Albert, 1983). In this book, he advocated for the development of an ambitious EEC industrial policy, based on standardization, the opening up of public procurement, and European loans to fund high-technology programs. Albert was quite an influential figure, having co-authored in 1984 the famous Albert-Ball report on European recovery commissioned by the European Parliament (Albert and Ball, 1984). In this book, Albert wrote the chapters which promoted the co-ordination of national industrial policy by the EEC, and the establishment of EEC policies in hightechnology (telecommunications, biotechnology, new transportation) to counter the US and Japanese competition. Albert's thinking was supported by the success of French state-driven industrial ventures, which was subsequently extended to Europe with some commercial success, such as the space launcher Ariane and the passenger aircraft Airbus.

In Paris, Élisabeth Guigou, Mitterrand's personal advisor for European affairs (and later on Minister for European Affairs) defended Michel Albert's ideas as early as mid1983. ${ }^{17}$ A couple of weeks later, in September 1983, the French government released a memorandum calling for the development of an ambitious EEC industrial policy. This move followed the near-financial crisis of Spring 1983 which forced the government to abandon the most nationalistic part of its economic policy, and hence to fully embrace European integration. The 1983 French memorandum echoed the Schuman declaration

\footnotetext{
${ }^{12}$ According to various studies by the European Commission and the OECD, see the full references in Warlouzet, 2018, p. 106.

${ }^{13}$ German national archives, B102/375364, note BMWi, 3 December 1981.

${ }^{14}$ EU archives (Commission), BAC104/1993/349/113, note from Caspari to Andriessen, 6 January 1982.

${ }^{15}$ AAPD/1982/211, note on a meeting Schmidt-Taylor, 14 July 1982

${ }^{16}$ EU archives (Commission), collection of discourses, Caspari, Cologne, 14 October 1981.

${ }^{17}$ French national archives, 5AG4/PM50/1, note Guigou, 24 August 1983; see Warlouzet, 2018, p. 126.
} 
of 9 May 1950, by referring to the 'de-facto solidarity' of European member states. It was predicated on the necessity of living up to the US and Japanese challenge in high technology. Like Albert's book, the memorandum promoted European industrial policies but with a more intergovernmental tone. It put an emphasis on the 'Community preference', by favouring EEC companies in public procurement markets in high technology. However, this notion of 'Community preference' was problematic given that French officials were unable to define precisely what a genuine 'EEC company' was, since many criteria could be used. ${ }^{18}$

In the end, this program was not implemented. Predictably, the European Commission was not enthusiastic about its intergovernmental tone. ${ }^{19}$ Moreover, the German government opposed what it considered a dirigist drift. Most of all, the French government itself was not ready to give up any significant power or funds to the European Commission so those projects went nowhere. However, Jacques Delors endeavoured to defend a Europeanized version of French industrial policy within the Commission, in particular in high technology (see below on Delors).

Later on, the conflict between DG Competition and French industrial policy still haunted by its Colbertist tendencies resurfaced. Three casus belli arose regularly: when the Commission banned mergers steered by French companies (ATR/De Havilland in 1991, Péchiney in 2000, Schneider/Legrand in 2001), when it forbade French state aid designed to help ailing companies, and when it liberalized sectors previously shielded from competition by removing specific privileges enjoyed by French state-owned companies (such as the SNCF in railways, Air France in air transportation, EDF in the electricity sector, etc.) (Cini and McGowan, 2009; Schmidt, 1996; Thatcher, 2007).

Those quarrels sometime resulted in high-profile political battles, both from centreright and from centre-left leaders. In 2007, the French President Nicolas Sarkozy opposed the insertion in the Lisbon Treaty of the reference to the 'free competition' in the Article on the Union's objectives. This move was significant because Article 3 of the Treaty of Rome included 'the establishment of a system ensuring that competition shall not be distorted in the Common Market' only as 1 among 11 tools designed to fulfill the objectives of the EEC laid out in Article 2. In the end, a compromise was struck: the reference to 'a system ensuring that competition is not distorted' was removed from the objectives of the Union, and relegated to protocol no.27 which deals exclusively with the internal market. Later on, on 14 January 2014, the French Minister of Industry, the socialist Arnaud Montebourg sent high-profile letters to the then-Commissioner for Competition Joaqim Almunia, accusing him of weakening the European industrial basis by a stern implementation of competition rules. Both Montebourg and Almunia were socialists but they clearly disagreed on what a 'social market economy' as defined in the European treaties meant.

\section{The Quest for Monetary Union and the Delors Synthesis}

From the 1970s onwards, monetary co-operation took central stage in European integration. In this area, West Germany was clearly a reference. It was known as 'Modell

\footnotetext{
${ }^{18}$ French national archives, 5AG4/PM/51, note SGCI, 7 October 1983.

${ }^{19}$ French national archives, 5AG4/PM/51, Com(83)547, 14 September 1983.
} 
Deutschland' in the 1970s because it maintained a persistent trade surplus despite a tenfold rise in oil prices and an expensive deutschmark. This strength was due to the traditional competitiveness of the German industry, but equally to the choice of a macro-economic policy geared towards stability, and hence towards weak inflation. West Germans had been traumatized by the hyperinflation of 1923 and by the currency manipulation of Hitler, whereas many of them had associated the so-called 'economic miracle' (Wirtschaftswunder) with Ludwig Erhard's decision to launch a new strong currency, the deutschmark, in June 1948. It was managed by a new Central Bank, the Bank Deutscher Länder (later reformed to become the Bundesbank in 1957), which limited its issuance in order to strengthen its value and to limit inflation. Those decisions fit well with the ordoliberal emphasis on macro-economic stability and on the management of the economy by independent authorities able to withstand political pressure (Dyson, 1992; Thiemeyer, 2013).

By contrast, up to the 1990 s, France was a country with relatively high inflation and a weak currency compared with West Germany. Those factors were associated with balance of payments problems and with high borrowing costs, which pushed Paris to the verge of a monetary crisis in 1968 and again in 1983. One advantage of a weak currency was to boost competitiveness but the French trade balance was perennially in deficit because French industry suffered from a lack of competitiveness, and because high inflation more than compensated for the weaker currency. Hence, French leaders became more and more interested in fostering monetary co-operation with Germany in order to bolster the French franc (and hence reduce inflation) and also obtain automatic support from the mighty Bundesbank in the event of a monetary crisis (Dyson and Featherstone, 1999; Howarth and Schild, 2017).

To convince the German government, several French leaders strived to promote a synthesis between French dirigism and German ordoliberalism. The first one was Raymond Barre, the professor of economics who became Prime Minister between 1976 and 1979. Emmanuel Mourlon-Druol demonstrated how important Barre's commitment to leading a stability-oriented macro-economic policy was in order to convince the German government to accept a stronger monetary co-operation with France (Mourlon-Druol, 2012). This eventually resulted in the European Monetary System (EMS).

\section{Delors and the Compromise Leading to EMU}

The decisive push for a Franco-German synthesis came with Jacques Delors. Delors was an unusual character on the French political scene (Drake, 2000). A Social-Christian trade unionist, he did not share the dirigist mentality based on the need to centralize all decisions on the State. Instead, he promoted the empowerment of trade unions, business organization and local authorities in the management of economic and social policies. As President of the European Commission (1985-95), he promoted a balanced vision associating free-market policies, socially-oriented policies and a neomercantilist vision (Warlouzet, 2018, pp. 192-194). This resulted in the promotion of the Single Market, enshrined in the Single Act Treaty (1986), but also in a vigorous promotion of European social and industrial policies. Delors' position was similar to that of the French governments, but he had a more pro-European and decentralized vision. For example, he promoted European social dialogue through tripartite negotiations between European trade 
unions, European business representatives and the European Commission, whereas the French government had always been wary of this approach. Similarly, Paris had promoted the development of a European technological policy outside the EEC, for example with the 1985 Eureka venture, whereas Delors strived to concentrate all initiatives within the Commission.

For Delors, monetary co-operation was a priority from the outset. A former official from the French Central Bank, the President of the Commission had promoted the deepening of European monetary co-operation as early as $1985 .{ }^{20}$ Delors was the French Minister of Economy and Finance in 1983 when France was on the verge of financial crisis. For him, a deepening monetary co-operation with Germany was the utmost priority to lower interest rates. It meant cheaper borrowing costs for companies, but also for the French state and for the French people (Abdelal, 2007). In this regard, European monetary co-operation was part of a social policy.

Delors played a decisive role in brokering a compromise between the French and the German governments. Of course, the President of the Commission's role was probably less important than the personal connection between the French President Mitterrand and the German Chancellor Kohl in the run-up to the Maastrich Treaty and to the European Monetary Union (Dyson and Featherstone, 1999; Dyson and Maes, 2016; Moravcsik, 1998; Verdun, 2002). Nevertheless, Delors played an important role in the shaping of a new European middle way between French dirigism and German ordoliberalism. It borrowed social and industrial policies from the former, and stability-oriented macro-economic policies from the latter, as well as a Social-Christian belief in subsidiarity, decentralization and humanistic policies. This philosophy was especially visible in some features of the Maastricht Treaty, such as the Social Protocol, and most of all in the 1993 White Paper Growth, Competitiveness and Employment (COM (93) 700) (European Commission, 1993).

The compromise between French dirigism and German ordoliberalism was enshrined in the 1991 Maastricht Treaty, especially in EMU. ${ }^{21}$ Certainly, countries with weak currencies bore the pressure to converge with the stability-oriented policies of strong currency countries. Nevertheless, European monetary integration cannot be interpreted as a unilateral German victory for four reasons. First, leaders of weak currency countries chose voluntarily to be inserted into a relatively constraining European framework as they were willing to converge towards the German economic policy, which was considered as a lodestar. Second, the German governments made huge concessions, such as abandoning the much-loved deutschmark. Third, weak currency countries also benefited from some solidarity. The German government did rescue some weak currency governments during certain monetary crises, notably the French franc in 1983 and in 1992. Fourth, weak currency countries benefited from lower interest rates when they were tied with strong currency countries.

However, the implementation of this Delors compromise is still an ongoing process, and it has not replaced the previous dirigist and ordoliberal tendencies. As Guido Thiemeyer has demonstrated, a sizeable opposition to the EMU emerged in both countries

\footnotetext{
${ }^{20}$ AAPD, 1985/311, note on a meeting Kohl-Delors, 11November 1985.

${ }^{21}$ More generally, on the economic debate over the EMU, see : Brunnermeier et al., 2016; Dyson and Maes, 2016; PisaniFerry, 2006; Sadeh and Verdun, 2009.
} 
in the 1990s in the name of safeguarding the national economic model (Thiemeyer, 2013). German ordoliberals were preoccupied by the threat on currency stability, whereas French dirigists feared for the superiority of the political authority over monetary matters. Later, during the euro crisis, the French project to set up an 'economic government' for the eurozone, contrasted with the German insistence of strictly abiding by the rules and of cutting deficits. On the whole, the Euro crisis controversies echo previous debates of the 1970s on the linkage between economic convergence and the transfer union, and to some extent about banking regulation and supervision (Mourlon-Druol, 2014).

\section{Conclusion}

Whereas neither French dirigism nor German ordoliberalism has exclusively dominated European integration, both of them have influenced the European policies conducted by many French and German officials. The Treaty of Rome, being flexible, was interpreted in very different ways. For officials influenced by ordoliberalism, an emphasis was placed on assigning a central role to competition policy and to a rule-based monetary union. Others strived to Europeanize the salient features of the French dirigist model, in particular through planning and industrial policy projects.

German ordoliberalism has enjoyed greater influence, manifesting itself in implemented policies: competition policy and the EMU - and not only in projects, such as European planning. However, the influence of French dirigism has been visible first through the EEC/EU tolerance for national dirigism, and also through certain European policies, such as support for R\&D.

This imbalance can be explained by an institutional factor: it seems easier to empower EEC institutions with a regulatory role, rather than with a redistributive one (Majone, 1994; Scharpf, 2009). Creating a European-wide planning agency or an EEC industrial policy would create massive distributive problems. By contrast, devolving rules seem innocuous, at least at first, before it is eventually too late to react because a path-dependency has been established (Warlouzet, 2016). Besides, the French government had never supported a full-scale transposition at the EEC level of its national dirigism, as it would have entailed intolerable delegations of power.

On the whole, both approaches have been mixed together over the course of European integration. Several important figures, such as Barre, Kohl and Delors, have striven to bridge the gap between the economic specificities of both countries. Delors' synthesis associating market-oriented, socially-oriented and neomercantilist policies - has been especially influential. Even if it has not been not fully implemented, it has helped the French and Germans to accept an EMU compromise. More broadly, the Delors synthesis helped to formulate more explicitly the European economic and social model. Subsequently, it was encapsulated in the expression 'social market economy', even if Delors himself did not use this term. It was inserted in the Treaty of Lisbon, with a more consensual meaning than its ordoliberal roots suggested.

Today, traditional approaches are still visible in the new political protest movements. In Germany, some of German's AfD founders were critical of the management of the eurozone crisis in the name of ordoliberal principles, while the French movement 'Les insoumis', which leads the left-wing opposition to President Macron, draws heavily on a dirigist rhetoric. 
Correspondence:

Laurent Warlouzet

University of Littoral-Côte d'Opale

8 rue de la vieille monnaie

45000 Orléans

France

email: laurent.warlouzet@univ-littoral.fr

\section{References}

Abdelal, R. (2007) Capital Rules. The Construction of Global Finance (Ithaca: Cornell University Press).

Albert, M. (1983) 'Un pari pour l'Europe'. In Vers le redressement de l'économie européenne dans les années 80 (Paris: Seuil).

Albert, M. and Ball, J. (1984) Toward European Economic Recovery in the 1980s. Report to the European Parliament, New-York: Praeger.

Beaune, C. (1993) Naissance de la nation France (Paris: Gallimard).

Berghahn, V. (1986) The Americanisation of West German Industry, 1945-1963 (New York: Berg).

Brubaker, R. (1992) Citizenship and Nationhood in France and in Germany (Harvard University Press: Cambridge, MA).

Brunnermeier, M., James, H. and Landau, J.-P. (2016) The euro and the Battle of Ideas (Princeton, NJ: Princeton University Press).

Buch-Hansen, H. and Wigger, A. (2011) 'The Politics of European Competition Regulation'. In A critical political economy perspective (Oxon: Routledge).

Cini, M. and McGowan, L. (2009) Competition Policy in the European Union (Basingstoke: Macmillan).

Coppolaro, L. (2013) 'The Making of a World Trading Power'. In The European Economic Community (EEC) in the GATT Kennedy Round Negotiations (1963-1967) (Aldershot: Ashgate).

Coppolaro, L. (2016) 'GATT, inflation and exchange rate instability Liberalising trade in the Tokyo Round negotiations (1973-1979)'. In Chélini, M.-P. and Warlouzet, L. (eds) Slowing Down Prices. European Inflation in the 1970s (Paris: Presses de Sciences-Po), pp. 323-41.

Drake, H. (2000) Jacques Delors. Perspectives on a European Leader (London: Routledge).

Dyson, K. (1992) 'Theories of Regulation and the Case of Germany'. In Dyson, K. (ed.) The Politics of German Regulation (Aldershot: Dartmouth), pp. 1-28.

Dyson, K. and Featherstone, K. (1999) The road to Maastricht: negotiating economic and monetary union (Oxford: Oxford University Press).

Dyson, K. and Maes, I. (eds) (2016) Architects of the Euro. Intellectuals in the Making of European Monetary Union (Oxford: Oxford University Press).

Elvert, J. (2004) 'Hans von der Groeben. Anmerkungen zur Karrieres eines deutschen Europäers der ersten Stunde'. In König, M. and Schulz, M. (eds) Bundesrepublik Deutschland und die europäische Einigung 1949-2000 (Stuttgart: Steiner), pp. 85-103.

European Commission (1993) Growth, competitiveness, employment. The challenges and ways forward into the 21st century: White paper.

Fioretos, O. (2011) Creative Reconstructions. Multilateralism and European Varieties of Capitalism after 1950 (Ithaca, NY: Cornell University Press).

Gerber, D.J. (1998) Law and competition in XXth Century Europe. Protecting Prometheus (Oxford: Clarendon Press).

Hall, P. and Soskice, D. (eds) (2001) Varieties of Capitalism. The Institutional Foundations of Comparative Advantage (Oxford: Oxford University Press). 
Howarth, D. and Schild, J. (2017) 'France and European Macro-economic Policy Coordination: From the Treaty of Rome to the Euro Area Sovereign Debt Crisis'. Modern \& Contemporary France, Vol. 25, No. 2, pp. 171-90.

Katzenstein, P. (1987) Policy and Politics in West Germany. The Growth of a Semisovereign State (Philadelphia, PA: Temple University Press).

Knudsen, A.-C. (2009) Farmers on Welfare. The Making of Europe's Common Agricultural Policy (Ithaca, NY: Cornell University Press).

Mudge, S. (2008) 'What is Neoliberalism?' Socio-Economic Review, Vol. 6, pp. 703-31.

McArthur, J. and Scott, B. (1969) Industrial Planning in France (Boston, MA: Harvard Business School).

Majone, G. (1994) 'The Rise of the Regulatory State in Europe'. West European Politics, Vol. 17, No. 3, pp. 77-101.

Milward, A. (1992) The European Rescue of the Nation State (London: Routledge).

Moravcsik, A. (1998) 'The Choice for Europe'. In Social Purpose and State Power from Messina to Maastricht (Ithaca, NY: Cornell University Press).

Mourlon-Druol, E. (2012) 'A Europe made of Money'. In The Emergence of the European Monetary System (Ithaca, NY: Cornell University Press).

Mourlon-Druol, E. (2014) 'Don't Blame the Euro: Historical Reflections on the Roots of the Eurozone Crisis'. West European Politics, Vol. 37, No. 6, pp. 1282-96.

Nicholls, A.J. (1994) 'Freedom with Responsibility'. In The Social Market Economy in Germany, 1918-1963 (Oxford: Clarendon Press).

Nützenadel, A. (2003) 'Die BRD, Frankreich und die Debatte über eine europäische Wirtschaftspolitik, 1958-65'. Francia, Vol. 30, No. 1, p. 3.

Patel, K.K. (ed.) (2009) Fertile Ground for Europe? The History of European Integration and the Common Agricultural Policy since 1945 (Baden-Baden: Nomos).

Pisani-Ferry, J. (2006) 'Only One Bed for Two Dreams: A Critical Retrospective on the Debate over the Economic Governance of the Euro Area'. JCMS, Vol. 44, No. 4, pp. 823-44.

Ramirez-Perez, S. and van der Scheur, S. (2013) 'The Evolution of the Law on Articles 85 and 86 EEC'. In Patel, K.K. and Schweitzer, H. (eds) The Historical Foundations of EU Competition Law (Oxford: Oxford University Press), pp. 19-53.

Ruggie, J.G. (1982) 'International Regimes, Transactions, and Change: Embedded Liberalism in the Postwar Economic System'. International Organization, Vol. 36, No. 2, pp. 379-415.

Scharpf, F. (2009) 'The Double Asymmetry of European Integration. Or: Why the EU Cannot Be a Social Market Economy', MPIfG Working Paper 09/12.

Sadeh, T. and Verdun, A. (2009) 'Explaining Europe's Monetary Union: A Survey of the Literature'. International Studies Review, Vol. 11, No. 2, pp. 277-301.

Schmidt, V.A. (1996) From State to Market? The Transformation of French Business and Government (Cambridge: Cambridge University Press).

Seidel, K. (2010) The Process of Politics in Europe: The Rise of European Elites and Supranational Institutions (London: I.B. Tauris).

Shonfield, A. (1965) Modern Capitalism. The Changing Balance of Public and Private Power (Oxford: Oxford University Press).

Thatcher, M. (2007) Internationalisation and Economic Institutions: Comparing the European Experience (Oxford: Oxford University Press).

Thiemeyer, G. (2013) 'Economic Models in France and Germany and the Debates on the Maastricht Treaty'. Journal of European Integration History, Vol. 19, No. 1, pp. 85-104.

Verdun, A. (2002) 'Why EMU happened? A survey of theoretical explanations'. In Crowley, P. (ed.) (Before and Beyond EMU. Historical lessons and future prospects, London: Routledge), pp. 71-98. 
Von der Groeben, H. (1964) 'Wettbewerb und Programmierung als Instrumente der Wirtschaftspolitik im Gemeinsamen Markt'. In Plitzko, A. (ed.) Planung ohne Planwirtschaft (Kyklos: Basel).

Warlouzet, L. (2011) Le choix de la CEE par la France. Les débats économiques de Pierre Mendès-France à Charles de Gaulle (1955-1969) (Paris: Cheff).

Warlouzet, L. (2016) 'The Centralization of EU Competition Policy. Historical Institutionalist Dynamics from Cartel Monitoring to Merger Control (1956-91)'. JCMS, Vol. 54, No. 3, pp. 725-41.

Warlouzet, L. (2018) Governing Europe in a Globalizing World. Neoliberalism and its Alternatives following the 1973 Oil Crisis (London: Routledge). 